\title{
Mathematical modeling of the process of obtaining raw material for manufacturing sorbents of medical purpose
}

\author{
(C) Ilnar A. Valeev, ${ }^{+}$Irina V. Zhukova, ${ }^{{ }^{+}}$and Azat A. Girfanutdinov \\ Kazan National Research Technological University (KNRTU). \\ Karl Marx St., 68. Kazan, 420015. Tatarstan Republic. Russia. \\ E-mail: zhukovka116@mail.ru
}

\begin{abstract}
*Supervising author; ${ }^{+}$Corresponding author Keywords: waste wood, charcoal, activated carbon, pyrolysis, pyrolysis plants, plants for charcoal burning, sorbents, activated carbon, mathematical model, modeling, enter sorbents, sorbents for medical purposes.
\end{abstract}

This article analyzes the production and use of affordable medical sorbents in the Russian and international markets. The analysis showed that there is a shortage of production of cheap specific activated carbon in Russia, due to insufficient expansion of the range. Today, the price of coal tends to increase, so many manufacturers are puzzled by the creation of an effective system for processing coal. It was suggested to use burnt charcoal from various types of wood, since it is one of the optimal types of sorbents, taking into account the economic aspect and the naturalness of the raw materials used for the production of activated carbon. An efficient and simple method of processing burnt coal-pyrolysis-was also proposed. Verification of the model's adequacy to the real process was performed by comparing the results of experimental studies with the results of theoretical calculations. The basic kinetic and thermophysical equations that are used today to study the kinetics of pyrolysis of activated carbon are studied. To find out whether a change in pressure can affect the course of the pyrolysis process, an experimental setup was developed and a series of experiments were conducted. Wood samples were used for experiments. $25 \times 25 \times 25 \mathrm{~mm}$ and humidity $10 \%$. The volume of one-time loading was $50 \mathrm{~g}$. The operating pressure in the pyrolysis chamber was recorded by a pressure gauge and set using ejector pumps (pressure reducers), whose performance was regulated and was $0.9,0.8,0.7,0.6$, $0.5 \mathrm{kPa}$, or a nitrogen cylinder (pressure increase) to the absolute pressure values $1,2,3,4,5,6 \mathrm{kPa}$.A comparative analysis of mathematical calculations and a number of experimental data conducted on warty birch was also carried out. A mathematical model of the wood pyrolysis process is proposed, which takes into account pre-drying, kinetics, the amount of volatile products released, and cooling of the finished charcoal.

\section{References}

[1] A.N. Grachev, I.A. Valeev, R.G. Safin, D.A. Khalitov. Nikolaev Nikolaev A.N. Petrov V.I . Thermochemical processing of wood by rapid pyrolysis. Woodworking industry. Moscow. 2009. No.3. P.21-24. (russian)

[2] R.R. Khasanshin, R.V. Danilova. Preliminary heat treatment of wood filler in the production of KDPM. Bulletin of Kazan State Technological University. Kazan. 2012. No.7. P.62-63. (russian)

[3] R.R. Khasanshin, R.R. Safin, R.V. Danilova. Improving the operational characteristics of composite materials based on thermally modified wood. Bulletin of Kazan State Technological University. Kazan. 2012. No.7. P. 64-66. (russian)

[4] N.R. Galyaveddinov, V.A. Lashkov, A.N. Nikolaev. Improving the manufacturing technology of woodfilled composite materials based on cement binders. Bulletin of Kazan Technological University. 2011. No.20. P.112-115. (russian)

[5] N.R. Galyaveddinov, F.G. Valiev, R.R. Khasanshin. Assessing the effect of heat treatment of wood filler on the performance properties of cement-bonded particle boards. Bulletin of Kazan Technological University. 2012. Vol.15. No.10. P.85-87. (russian)

[6] I.A. Valeev. Mathematical modeling of the process of wood pyrolysis with regulation of environmental pressure. Woodworking industry. 2012. No.3. P.41-46. (russian)

[7] I.Z. Fayzullin, I.V. Imamutdinov, V.Ya. Khamidov, I.N. Musin, S.I. Wolfson. Influence of fillers and technological additives on the rheological properties of wood - polymer composites. Bulletin of Kazan Technological University, Kazan, KNITU. 2013. Vol.16 No.10. P.148-150. (russian)

[8] I.N. Musin, I.Z. Fayzullin, S.I. Wolfson. Modification of wood-polymer composites based on polyolefins with montmorillonite. Bulletin of Kazan Technological University. Kazan, KNITU. 2012. No.14. P.135-138. (russian) 